\title{
ANALISIS PENGGUNAAN PEMBIAYAAN MUDHARABAH DAN PEMBIAYAAN MUSYARAKAH TERHADAP PROFITABILITAS DI BANK UMUM SYARIAH PERIODE 2015-2018
}

\author{
Oleh : \\ Heikal Muhammad Zakaria \\ Fakultas Ekonomi - Universitas Singaperbangsa Karawang \\ heikalzakaria@fe.unsika.ac.id \\ Gusganda Suria Manda \\ Fakultas Ekonomi - Universitas Singaperbangsa Karawang \\ gusganda.suriamanda@fe.unsika.ac.id
}

Arif Rakhman

Fakultas Ekonomi - Universitas Singaperbangsa Karawang

arif.rakhman@fe.unsika.ac.id

\begin{tabular}{l}
\hline Article Info \\
\hline Article History: \\
Received 29 July - 2020 \\
Accepted 20 August - 2020 \\
Available Online \\
07 Sept - 2020
\end{tabular}

Keyword :

Mudharabah Financing,

Musyarakah Financing,

Profitability (ROA).

\begin{abstract}
This study is aiming to determine the effect of mudharabah financing on the profitability (ROA) in Sharia Commercial Banks (BUS) for the 2015-2018 period, the effect of musyarakah financing on the profitability (ROA) on Sharia Commercial Banks (BUS) for the 2015-2018 period, and the effect of mudharabah and musyarakah financing on the profitability (ROA) in Sharia Commercial Banks (BUS) for the 2015-2018 period. This research is a type of associative research with a quantitative approach. This study uses secondary data with the period of 2015-2018 observation. The data used is sourced from the Sharia Banking (SPS) and the Sharia Bank's annual financial statements from 2015 to 2018. The analysis used is multiple linear regression analysis. Data is processed using SPSS version 16. The results of the study show that mudharabah financing has a significant positive effect on the profitability (ROA) of Sharia Commercial Banks (BUS) for the 2015-2018 period. Musyarakah financing has a significant negative effect on profitability (ROA) of Sharia Commercial Banks (BUS) for the 2015-2018 period. Mudharabah financing and musyarakah financing have a positive significant effect on the profitability (ROA) of Sharia Commercial Banks (BUS) for the 2015-2018 period.
\end{abstract}

\section{PENDAHULUAN}

Salah satu alat analisis yang digunakan dalam menghitung sejauh mana sebuah perusahaan mampu menghasilkan keuntungan adalah dengan menggunakan rasio profitabilitas. Menurut Sudana (2011) profitabilitas adalah kemampuan perusahaan untuk menghasilkan keuntungan dengan menggunakan sumber daya yang dimiliki seperti aset, modal atau penjualan perusahaan. Artinya, semakin tinggi tingkat profitabilitas dalam sebuah perusahaan, hal ini menunjukkan bahwa semakin baik kinerja manajemen dalam menghasilkan keuntungan. Sebaliknya, jika tingkat profitabilitas yang dicapai rendah, maka hal itu menunjukkan bahwa kinerja manajemen yang rendah dalam menghasilkan keuntungan. Sama seperti dengan perbankan 
konvensional, kelangsungan usaha Bank Syariah sangat dipengaruhi oleh kualitas investasi dana yang dilakukan. Aset produktif yang ada di Bank Syariah menggunakan sistem pembiayaan. Salah satu produk pembiayaan yang tersedia di Bank Syariah adalah pembiayaan modal kerja, pemberian modal kerja yang dapat berupa pembiayaan Mudharabah dan pembiayaan musyarakah.

\section{KAJIAN PUSTAKA PEGEMBANGAN HIPOTESIS Bank Syariah}

Berdasarkan pendapat oleh Ramlan dan Adnan (2015) sistem perbankan dunia ada dua jenis bank. Yang satu adalah sistem perbankan berbasis minat yang disebut sebagai sistem perbankan konvensional dan yang lainnya adalah sistem perbankan bebas bunga disebut sebagai sistem perbankan Islam. Menurut UU Republik Indonesia No. 10 tahun 1998, definisi Bank Syariah adalah bank yang menjalankan kegiatan usaha berdasarkan prinsip Syariah yang dalam kegiatannya memberikan jasa dalam pembayarannya. Jadi, Bank Syariah adalah bank yang melaksanakan kegiatan usahanya berdasarkan Syariah Islam. Prinsip yang digunakan oleh Bank Islam adalah untuk menjauhkan unsur bunga atau riba. Hukum Islam sendiri telah melarang bunga atau riba sebagaimana tertulis dalam Al-Qur'an ayat 130. Sehingga dalam kegiatan usahanya Bank Syariah tidak menerapkan prinsip kepentingan karena Bank Syariah membangun sistem keterbukaan dan keadilan.

\section{Pembiayaan Mudharabah}

Menurut PSAK 105 menyatakan definisi tentang Mudharabah. Mudharabah didefinisikan sebagai kontrak kerjasama bisnis antara dua pihak di mana pihak pertama (pemilik dana atau shahibul maal) menyediakan semua dana, sementara pihak kedua (manajer investasi atau mudarib) bertindak sebagai manajer, dan keuntungan dibagi antara mereka sesuai dengan perjanjian sementara kerugian keuangan hanya ditanggung oleh pemilik dana. Kerugian akan ditanggung oleh pemilik dana selama kerugian tersebut tidak disebabkan oleh kelalaian manajer investasi, jika kerugian tersebut disebabkan oleh kelalaian manajer investasi, kerugian ini akan ditanggung oleh manajer investasi tersebut. Jadi, Mudharabah adalah sebuah kolaborasi antara pemilik dana dan manajer investasi yang bertujuan untuk mendapatkan pengembalian bisnis yang dijalankan sehingga keuntungan yang diperoleh dapat dibagi sesuai dengan kontrak pada awal perjanjian, dan jika ada kerugian pemilik dana akan menanggung.

\section{Pembiayaan Musyarakah}

Menurut PSAK 106, definisi musyarakah. Musyarakah adalah kontrak kerja sama antara 2 pihak atau lebih untuk bisnis tertentu di mana masing-masing pihak menyumbang dana dengan ketentuan bahwa keuntungan dibagi dengan perjanjian sementara kerugian didasarkan pada kontribusi dana. Jadi, musyarakah adalah kontrak kerjasama antara pemilik modal yang mencampur modal mereka dengan tujuan untuk membuat keuntungan.

\section{Profitabilitas}

Berdasarkan pendapat dari barus dan Leliani (2013) profitabilitas adalah kemampuan untuk menghasilkan keuntungan untuk jangka waktu tertentu menggunakan aset atau modal, baik modal secara keseluruhan dan modal sendiri. Menurut Wahyuningsih (2017) profitabilitas merupakan tolok ukur keberhasilan sebuah perusahaan dengan melihat efisiensi penggunaan modal. Sehingga profitabilitas adalah kemampuan perusahaan untuk menghasilkan keuntungan dari pemanfaatan aset atau modal sendiri.

\section{Return On Assets (ROA)}

Laba atas aset adalah rasio yang menunjukkan berapa banyak aset yang berkontribusi untuk menciptakan laba bersih. Dengan kata lain, rasio ini digunakan untuk mengukur berapa banyak pendapatan bersih yang akan dihasilkan dari masing-masing dana yang ditanamkan dalam total aset. Semakin tinggi laba atas aset berarti semakin tinggi jumlah pendapatan bersih yang dihasilkan dari setiap dana rupiah yang ditanamkan dalam total aset.

\section{Pengembangan Hipotesis}

Ada beberapa perbedaan pendapat menurut penelitian sebelumnya tentang efek pembiayaan Mudharabah terhadap profitabilitas, menurut Afkar (2017) dan putra (2018) menyatakan bahwa pembiayaan Mudharabah tidak berpengaruh signifikan terhadap profitabilitas hal ini disebabkan Mudharabah merupakan skema pembiayaan dengan cara pembagian keuntungan yang ditentukan oleh kedua belah pihak, sehingga terdapat kemungkinan risiko yang signifikan 
terhadap pembiayaan bermasalah dan memiliki efek pada kemampuan perbankan Syariah untuk mendapatkan keuntungan. Dan juga ketidakpastian dalam memperoleh laba sehingga bank cenderung kurang berminat dalam mendistribusikan pembiayaan Mudharabah. Pendapat ini bertentangan dengan pendapat Rahayu, Husaini, Azizah (2016) dan Yentisna dengan Alvian (2019) pembiayaan Mudharabah mempunyai efek positif yang signifikan pada profitabilitas karena nilai nominal pembiayaan terdistribusi telah meningkat secara signifikan. Perbedaan dalam hasil studi ini disebabkan oleh perbedaan lokus atau sampel dan periode yang digunakan.

Ada perbedaan pendapat tentang pembiayaan musyarakah terhadap profitabilitas menurut Oktriani (2012) dan Aditya (2016) pembiayaan musyarakah tidak berpengaruh dan tidak signifikan pada profitabilitas karena jumlah pembiayaan yang didistribusikan telah meningkat namun jumlah risiko pembiayaan musyarakah meningkat dari tahun ke tahun. Pendapat ini bertentangan dengan opini yang menurut Pratama, Martika, Rahmawati (2017) yang menyatakan bahwa pembiayaan musyarakah memiliki dampak positif dan signifikan terhadap tingkat profitabilitas karena pembiayaan musyarakah memiliki tingkat resiko yang lebih rendah dibandingkan dengan pembiayaan Mudharabah. Perbedaan dalam hasil studi ini disebabkan oleh perbedaan lokus atau sampel dan periode yang digunakan.

Dan secara simultan efek Mudharabah dan pembiayaan musyarakah dalam hal profitabilitas, menurut negara Nurzianti (2017) yang bersama-sama (simultan) pembiayaan Mudharabah dan pembiayaan musyarakah tidak berpengaruh pada profitabilitas ini karena distribusi Mudharabah dan pembiayaan musyarakah masih belum produktif dan tidak banyak orang yang berminat untuk pembiayaan ini. Pendapat ini bertentangan dengan pandangan Aditya (2016) dengan Wibowo dan sunarto (2015) secara simultan, Mudharabah dan musyarakah pembiayaan memiliki pengaruh signifikan pada profitabilitas karena ditunjukkan oleh peningkatan jumlah keuntungan yang dihasilkan juga meningkat. Perbedaan hasil studi ini disebabkan oleh perbedaan lokus atau sampel dan periode yang digunakan.

\section{METODE PENELITIAN}

Dalam hal ini, populasi bank umum syariah yang terdaftar dalam Statistik Perbankan Syariah di 2018 adalah 8 Bank. Untuk menentukan sampel yang akan digunakan dalam studi, ada berbagai teknik sampling yang digunakan. Teknik sampling pada dasarnya dibagi menjadi dua, ada kemungkinan sampling dan nonprobabilitas sampling. Dalam studi ini, teknik sampling yang digunakan adalah sampling nonprobabilitas. Dan sampel diambil oleh metode purposive sampling. Sampling purposive menurut Sujarweni (2016) adalah teknik sampling dengan kriteria tertentu. Kriteria yang digunakan untuk mengambil sampel dalam studi ini adalah:

1. Bank Umum Syariah yang terdaftar pada 2018.

2. Bank Umum Syariah yang menerbitkan laporan keuangan tahunan dan laporan untuk periode 31 Desember 2015 hingga 2018 dinyatakan dalam rupiah.

3. Bank Umum Syariah yang memiliki data lengkap mengenai variabel yang sedang dipelajari adalah pembiayaan Mudharabah dan pembiayaan musyarakah.

Karakteristik seleksi sampel di atas diperoleh oleh bank umum syariah yang menjadi contoh kajian. Tabel berikut menyajikan hasil sampel studi:

Table 1 Prosedur seleksi sampel

\begin{tabular}{|c|c|c|}
\hline No. & Description & Total \\
\hline 1 & $\begin{array}{l}\text { Jumlah bank umum syariah yang } \\
\text { didaftarkan pada } 2015-2018 \text {. }\end{array}$ & 14 \\
\hline 2 & $\begin{array}{l}\text { Jumlah bank komersial Syariah yang } \\
\text { mempublikasikan Laporan Keuangan } \\
\text { Tahunan dan laporan periode } 31 \text { Desember } \\
2015 \text { hingga } 2018 \text { dinyatakan dalam } \\
\text { rupiah. }\end{array}$ & 14 \\
\hline 3 & $\begin{array}{l}\text { Jumlah bank yang tidak sesuai dengan } \\
\text { kriteria untuk ketersediaan data 2015- } \\
2017\end{array}$ & (4) \\
\hline \multirow[t]{2}{*}{4} & $\begin{array}{l}\text { Jumlah bank umum syariah yang } \\
\text { memiliki data lengkap mengenai variabel } \\
\text { yang sedang dipelajari adalah pembiayaan } \\
\text { Mudharabah dan pembiayaan musyarakah }\end{array}$ & 8 \\
\hline & $\begin{array}{l}\text { Total sampel yang digunakan ( } 4 \text { tahun } \\
\text { pengamatan, data per tahun) }\end{array}$ & $\begin{array}{c}8 \times 4= \\
32\end{array}$ \\
\hline
\end{tabular}

Source: Data Processed

Studi ini menggunakan teknik pengumpulan data dalam bentuk metode dokumentasi. Metode dokumentasi ini dilakukan dengan mengumpulkan data sekunder dari berbagai sumber. Sumber data yang dapat 
dimanfaatkan, ada www.bnisyariah.co.id, www.bankmuamalat.co.id, www.syariahmandiri.co.id www.brisyariah.co.id, www.paninbanksyariah.co.id, www.bcasyariah.co.id www.syariahbukopin.co.id www.bankvictoriasyariah.co.id. Data yang dikumpulkan adalah dalam bentuk Laporan Keuangan Bank Islam untuk 2015-2018 dan data terkait yang berfungsi untuk menghitung variabel dependen dan variabel independen.

\section{HASIL DAN PEMBAHASAN}

\section{Pengaruh Pembiayaan Mudharabah Terhadap Profitabilitas}

Berdasarkan t-Test ini dapat dilihat bahwa pembiayaan Mudharabah berdampak signifikan terhadap profitabilitas. Hal ini dibuktikan dengan hasil perhitungan SPSS, dimana signifikansi yang dihasilkan untuk variabel pembiayaan Mudharabah adalah 0000. Karena nilai signifikansinya di bawah 0,05 , ha yang menyatakan bahwa pembiayaan Mudharabah berdampak pada profitabilitas yang dapat diterima.

Variabel Mudharabah memiliki dampak positif dan signifikan terhadap profitabilitas di bank komersial Islam untuk periode 20152018. Hal ini dibuktikan dengan koefisien regresi 0,683 dan nilai $t$ dihitung lebih besar dari t Meja, di mana t Count adalah 6,235 dan meja t adalah 2,042.

Menurut PSAK 105 menyatakan definisi tentang Mudharabah yang didefinisikan sebagai kontrak kerjasama bisnis antara dua pihak di mana pihak pertama (pemilik dana atau shahibul maal) menyediakan semua dana, sementara pihak kedua (Fund Manager atau mudarib) bertindak sebagai manajer, dan keuntungan dibagi antara mereka sesuai dengan perjanjian sementara kerugian keuangan hanya ditanggung oleh pemilik dana. Kerugian akan ditanggung oleh pemilik dana selama kerugian tersebut tidak disebabkan oleh kelalaian manajer investasi, jika kerugian tersebut disebabkan oleh kelalaian manajer investasi, kerugian ini akan ditanggung oleh manajer investasi. Jadi, Mudharabah adalah sebuah kolaborasi antara pemilik dana dan manajer investasi yang bertujuan untuk mendapatkan pengembalian bisnis yang dijalankan sehingga keuntungan yang diperoleh dapat dibagi sesuai dengan kontrak pada awal perjanjian, dan jika ada kerugian pemilik dana akan menanggung. Pembiayaan Mudharabah merupakan perbandingan antara jumlah pembiayaan Mudharabah dan pembiayaan Total, jika pembiayaan meningkat, akan meningkatkan profitabilitas. Dalam pembiayaan Bank Mudharabah, pembagian keuntungan disepakati antara bank dan nasabah. Untuk hasil, tentu saja untuk Bank adalah pendapatan. Hal ini sesuai dengan teori yang disebutkan sebelumnya bahwa semakin tinggi pembiayaan Mudharabah, semakin tinggi profitabilitas (ROA).

Hasil kajian ini menyatakan bahwa pembiayaan Mudharabah memiliki efek positif yang signifikan, hal ini terjadi karena kemudahan sistem pembagian keuntungan dan persyaratan untuk memperoleh pembiayaan Mudharabah, sehingga akan berdampak pada kepentingan nasabah dalam mengembangkan usaha kecil dan menengah di Bank Syariah. Perbankan Syariah menyadari bahwa peningkatan pendapatan terutama dari pembiayaan Mudharabah dapat menyebabkan peningkatan profitabilitas (ROA). Oleh karena itu Bank membutuhkan profesionalisme dan kehati-hatian dalam mengelola pembiayaan Mudharabah. Mengingat bahwa pembiayaan Mudharabah termasuk dalam jenis kontrak urcenture alami, atau produk yang membawa ketidakpastian pendapatan.

Hasil kajian ini sejalan dengan penelitian yang dilakukan oleh Rahayu, Husaini, dan Azizah (2016). Hasil dari kajian ini menyatakan bahwa Mudharabah, pembiayaan pembagian keuntungan memiliki dampak positif yang signifikan terhadap profitabilitas karena nilai nominal penyaluran pembiayaan telah meningkat secara signifikan.

\section{Pengaruh Pembiayaan Musyarakah Terhadap Profitabilitas}

Berdasarkan uji $t$ dapat dilihat bahwa pembiayaan musyarakah berdampak signifikan terhadap profitabilitas. Hal ini dibuktikan dengan hasil perhitungan SPSS, dimana signifikansi yang dihasilkan untuk variabel pembiayaan musyarakah adalah 0,002 . Karena nilai signifikansinya di bawah 0,05 , ha yang menyatakan bahwa pembiayaan musyarakah memiliki efek pada profitabilitas yang dapat diterima. Variabel Syariah memiliki dampak negatif dan signifikan pada tingkat profitabilitas di bank komersial Islam untuk periode 2015-2018. Hal ini dibuktikan dengan koefisien regresi-0,516, dan t Count lebih kecil dari t Meja, t Count-3,331, dan t meja 2,042.

Menurut PSAK 106, definisi pembiayaan musyarakah adalah kontrak kerja sama antara 2 pihak atau lebih untuk usaha tertentu dimana 
masing-masing pihak menyumbang dana dengan ketentuan bahwa keuntungan dibagi berdasarkan perjanjian sementara kerugian didasarkan pada kontribusi dana. Jadi, musyarakah adalah kontrak kerjasama antara pemilik modal yang mencampur modal mereka dengan tujuan untuk menghasilkan keuntungan.

Pengaruh negatif dapat disebabkan oleh risiko pembiayaan musyarakah yang cukup besar sehingga dapat mempengaruhi profitabilitas (ROA) Bank Syariah. Menurut Saputra, Arifin, dan Zahroh (2015) pembiayaan merupakan pendapatan terbesar bagi Bank Syariah yang berisiko tinggi. Risiko pembiayaan timbul jika Nasabah tidak membayar profit Share dan kepala sekolah telah disediakan oleh Bank Syariah sesuai dengan kesepakatan. Penyebab utama risiko pembiayaan adalah bahwa Bank terlalu mudah untuk menyalurkan pembiayaan karena mereka diminta untuk menggunakan kelebihan dana. Sehingga penilaian calon mitra dilakukan kurang cermat.

Dalam kajian ini, efek negatif hasil dari pembiayaan musyarakah terhadap profitabilitas (ROA) karena banyaknya jumlah kredit yang dikumpulkan di Bank dan tidak memperoleh keuntungan, dan akhirnya akan berdampak pada penurunan ROA. Pembiayaan musyarakah tertinggi dimiliki oleh Bank Muamalat Indonesia dan Bank Syariah Mandiri, namun pembiayaan yang tinggi ini tidak diikuti oleh tingkat profitabilitas tinggi (ROA), dapat ditafsirkan bahwa semakin tinggi penyaluran pembiayaan musyarakah tidak menjamin bahwa profitabilitas (ROA) juga akan meningkat.

Sebaliknya, profitabilitas tertinggi (ROA) dimiliki oleh Bank BNI Syariah, meskipun penyaluran pembiayaan tidak lebih tinggi dibandingkan dengan Bank Muamalat Indonesia dan Bank Syariah Mandiri. Hal ini dikarenakan ketika pembiayaan Mutanaqisah meningkat, dana yang dikeluarkan juga semakin besar untuk memenuhi pembiayaan pembagian keuntungan, sedangkan pendapatan pembagian keuntungan dari pembiayaan musyarakah yang ditentukan dari rasio masih akan diterima di masa mendatang sesuai dengan kontrak yang ditetapkan.

Selain itu, risiko lain yang diakibatkan dari pembiayaan musyarakah adalah ketidakpastian pendapatan, karena produk ini termasuk dalam produk kontrak urcenture alami. Pembiayaan dengan sistem pembagian keuntungan ini memiliki risiko tinggi dalam hal kerugian yang dapat terjadi pada masa pembiayaan, sehingga dapat mengurangi keuntungan perusahaan karena pembiayaan pembagian keuntungan tidak hanya berbagi keuntungan, tetapi juga berbagi kerugian.

Hasil kajian ini sejalan dengan penelitian yang dilakukan oleh Samanto dan Yozika (2018) yang berhak atas hasil kajian yang menyatakan bahwa pembiayaan musyarakah memiliki efek negatif secara statistik terhadap profitabilitas (ROA).Effect of Mudharabah Financing and Musyarakah Financing on Profitability (ROA) Berdasarkan tabel uji F di atas, dapat dilihat bahwa SIG adalah 0000 maka kurang dari 0,05 sehingga Ho ditolak atau Ha diterima, dapat dikatakan bahwa pembiayaan Mudharabah dan pembiayaan musyarakah mempengaruhi profitabilitas (ROA). Hal ini dibuktikan dengan nilai $\mathrm{F}$ dihitung lebih besar dari tabel $\mathrm{F}$, di mana jumlah $\mathrm{F}$ adalah 22.512 dan tabel $\mathrm{F}$ adalah 3.340. Pembiayaan Mudharabah dan pembiayaan musyarakah memiliki efek positif pada profitabilitas dalam hal ini dapat dilihat dengan bertambahnya jumlah keuntungan yang meningkat dari tahun ke tahun.

Pengaruh Mudharabah dan musyarakah terhadap profitabilitas adalah $60 \%$. Sedangkan sisanya $40 \%$ dipengaruhi oleh faktor lain yang tidak dijelaskan dalam kajian ini. Nilai dari pengaruh ini menunjukkan nilai yang tidak terlalu besar, hal ini dikarenakan dalam kajian ini hanya mencakup dua jenis pembiayaan yaitu pembiayaan Mudharabah dan pembiayaan musyarakah, sedangkan pembiayaan di Bank Syariah bukan saja masih ada yang lain seperti pembiayaan Murabahah, pembiayaan Qardh dan lain-lain.

Selain itu, hal ini mempengaruhi profitabilitas Bank tidak hanya dari faktor pembiayaan, tetapi dari jumlah faktor modal, perencanaan bunga bank dan lain-lain.

Hasil kajian ini sejalan dengan penelitian yang dilakukan oleh Aditya (2016) yang bertajuk hasil kajian yang menyatakan bahwa pembiayaan Mudharabah dan pembiayaan musyarakah memiliki pengaruh signifikan terhadap profitabilitas karena ditandai dengan meningkatnya jumlah laba yang dihasilkan juga meningkat. 


\section{KESIMPULAN}

Kajian ini bertujuan untuk menentukan efek pembiayaan Mudharabah dan pembiayaan musyarakah atas profitabilitas (ROA) bank umum syariah untuk periode 2015-2018. Berdasarkan penelitian yang telah dilakukan, hal-hal berikut dapat disimpulkan:

a. Pembiayaan Mudharabah sebagian memiliki efek positif yang signifikan pada profitabilitas (ROA) bank umum syariah untuk periode 2015-2018. Keuntungan dari pembiayaan Mudharabah dapat memaksimalkan kemampuan bank untuk menghasilkan keuntungan, yang profit akan mempengaruhi profitabilitas (ROA).

\section{REFERENSI}

Aditya, Muhammad Rizal. 2016. Pengaruh Pembiayaan Mudharabah dan Pembiayaan Musyarakah Terhadap Tingkat Profitabilitas Bank Umum Syariah Periode 2010-2014. Jurnal Profita Edisi 4.

Afkar, Taudlikhul. 2017. Influence Analysis Of Mudharabah Financing and Qardh Financing To The Profitability Of Islamic Banking In Indonesia. Asian Journal of Innovation and Enterpreneurship (AJIE). Volume 2, No. 03. e-ISSN:2477-0574 ; p-ISSN:2477-3824

Barus, Andreani Caroline, dan Leliani. 2013. Analisis Faktor-Faktor yang Mempengaruhi Profitabilitas pada Perusahaan Manufaktur yang Terdaftar di Bursa Efek Indonesia. Jurnal Wira Ekonomi Mikrosil. Volume 3 Nomor 02; 112 ISSN: 2622-6421

Ghozali, Imam. 2011. Aplikasi Analisis Multivariate Dengan Program SPSS. Semarang: Badan Penerbit Universitas Diponegoro. Semarang.

Nurzianti, Rahma. 2017. Pengaruh Pembiayaan Mudharabah dan Pembiayaan Musyarakah Terhadap Profitabilitas (Studi Pada Bank Umum Syariah Di Indonesia Tahun 2015). STAIN Gajah Putih Takengon

Oktriani, Yesi. (2012). Pengaruh pembiayaan musyarakah, mudharabah dan murabahah terhadap profitabilitas (studi kasus pada PT. Bank Muamalat Indonesia, Tbk.). Jurnal Jurusan Akuntansi Fakultas Ekonomi Universitas Siliwangi.

Ramlan, Hamidah dan Adnan, Mohd Sharrizat. 2015. The Profitability of Islamic and Conventional Bank: Case study in Malaysia. University Tenaga Nasional.Malaysia b. Pembiayaan musyarakah sebagian memiliki efek negatif yang signifikan terhadap profitabilitas (ROA) bank umum syariah untuk periode 20152018. Laba pembiayaan musyarakah masih belum

c. dapat memaksimalkan kemampuan manajemen Bank untuk menghasilkan keuntungan, yang profit akan berdampak pada profitabilitas (ROA).

d. Pembiayaan Mudharabah dan pembiayaan musyarakah secara simultan memiliki efek positif pada profitabilitas (ROA) bank umum syariah untuk periode 2015-2018. Keuntungan dari pembiayaan Mudharabah dan pembiayaan musyarakah dapat memaksimalkan kemampuan bank untuk menghasilkan keuntungan, yang profit akan mempengaruhi profitabilitas (ROA).

Sudana, I Made. 2011. Manajemen Keuangan Perusahaan. Erlangga, Jakarta. UndangUndang Republik Indonesia Nomor 10 Tahun 1998 tentang perbankan

Wahyuningsih,Indah. 2017. Pengaruh Pendapatan Pembiayaan Mudharabah terhadap Profitabilitas (ROA) pada PT Bank Muamalat Indonesia Tbk Periode 2011-2015. Journal Economic and Business of Islam. Volume 2 No 2. e ISSN:2528-0325 ISSN:2528-0317

Wibowo, Arief dan Sunarto. 2015. Pengaruh Pembiayaan Mudharabah dan Musyarakah Terhadap Profitabilitas Perbankan Syariah (Studi Kasus pada Bank Pembiayaan Rakyat Syariah Daerah Istimewa Yogyakarta yang terdaftar di Bank Indonesia Periode 20122014. Syariah Accounting Paper FEB UMS. ISSN:2460-0784

Putra, Purnama.2018. Pengaruh Pembiayaan Mudharabah, Musyarakah, Murabahah, dan Ijarah Terhadap Profitabilitas 4 Bank Umum Syariah Periode 2013-2016. Jurnal Organisasi dan Manajemen, Volume 14 No. 2 ISSN:2442-9155.

Pratama, Ditha Nada, Lia Dwi Martika dan Teti Rahmawati.2017. Pengaruh Pembiayaan Mudharabah, Pembiayaan Musyarakah dan Sewa Ijarah Terhadap Profitabilitas. Jurnal Riset Keuangan dan Akuntansi (JRKA). Volume 3 Issue 1 e-Issn: 2621-3265 ISSN:2442- 4684

Rahayu, Yeni Susi, Achmad Husaini dan Devi Farah Azizah. 2016. Pengaruh Pembiayaan Bagi Hasil Mudharabah dan Musyarakah Terhadap Profitabilitas (Studi pada Bank Umum Syariah yang terdaftar pada Bursa Efek Indonesia periode 2011-2014). Jurnal Administrasi Bisnis (JAB). Volume 33 No. 1 